\title{
The Role of Intellectual Capital and Competitive Advantage in Increasing Market Stock Price
}

\author{
Sri Handayani ${ }^{1 *}$, Yosevin Karnawati $^{1}$ \\ ${ }^{1}$ Accounting Department, Faculty of Economics and Business, Universitas Esa Unggul, Jakarta, Indonesia \\ "Corresponding author. Email: sri.handayani@esaunggul.ac.id
}

\begin{abstract}
The purpose of this study was to analyze the effect of intellectual capital represented by the capital coefficient, human capital, structural capital, and competitive advantage toward stock market prices. The research subject is the mining industry in Indonesia. The unit of analysis is the mining sector which was listed in the Indonesia Stock Exchange (IDX) from 2016 to 2018. The total population is 123 data, while the sampling method is the saturated sampling, so the number of samples is 123 . Data analysis method used is the explanatory causal method. The analytical tool used is multiple linear regression. The results showed that intellectual capital consisting of value-added capital coefficient, value-added human capital, structural capital value-added, and competitive advantage simultaneously and significantly affects stock market price. As the results of partial data processing, structural capital value-added and competitive advantage significantly affects stock market price. Meanwhile, value-added capital coefficient and value-added human capital have no effect on stock market price. The finding of this study is that structural capital value-added and competitive advantage have the ability to increase stock market price in the capital market. The conclusion is that the structural capital value-added and competitive advantage can be called as an information that has relevance value in investors' decision making.

Keywords : Intellectual Capital, Value-Added Capital Coefficient, Value-Added Human Capital, Structural Capital Value-Added, Competitive Advantage, Stock Market Price
\end{abstract}

\section{INTRODUCTION}

Stock market price is the market value of a security that an investor can obtain, if the investor sells or buys shares. Theoretically, the investors' interests in company shares are influenced by the information they get about the state of the company. In addition to knowing the company's performance, financial reports also provide how the company's system works.

Recently, the world of business has changed. The business world has changed from a labor-based business to a knowledge-based business. The Resource-Based Theory (RBT) discusses how companies can achieve competitive advantage by developing and analyzing the resources they have, which highlights the advantages of knowledge or an economy that relies on intangible assets. One of the approaches used in the assessment and measurement of knowledge assets is Intellectual Capital (IC). [1] explained that IC has the potential to advance organizations and society, due to its relation to the knowledge and experience and the technology used. The real forms of IC include science and technology, design and implementation of new systems or processes, licenses, intellectual property rights, knowledge of markets and trademarks, computer software, patents, copyrights, live picture films, customer lists, forest tenure rights, import and export quotas, franchising, supplier or customer relationships, customer loyalty, marketing rights, and market share. IC is a positive interaction between employee competencies, internal organizational structure, and external or market relations. In general, experts and researchers argue that there are at least three components of intellectual capital, namely human capital (HC), structural capital (SC), and customer capital (CC). Value-Added Capital Coefficient (VACA) shows how successfully a company uses its tangible assets. Human capital reflects the collective ability of a company to provide the best solutions based on the knowledge possessed by the human resources in the company.

With good human capital, the company is expected to make profit. This becomes a positive information for investors so that it can increase the stock market price. Value-added human capital coefficient (VAHU) shows how much addedvalue is created by one unit of money invested in employees. Optimal human resource management can create added-value for the company, and will affect firm value, thereby increasing the stock market price. Structural Capital Value-Added (STVA) measures how much it takes to produce Rp. 1 of VA. In intellectual capital, labor load is an asset, not a cost, but it is treated as an asset so that this labor-load is called human capital. Intellectual capital has been considered as a major strategy in many large companies to gain competitive advantage and improve the market stock price [2]. 
Competitive advantage is one of the important variables in facing business competition. Company resources must have four attributes to generate potential competitive advantage, including a) Valuable by taking advantage of penetration opportunities or threats; b) Rare among current and potential competitors; c) Not perfectly replicable; and d) No substitute for equivalent resources [3] [4] [5]. When a company has a qualified IC, it will create value compared to competitors so that it will create a competitive advantage [6] [7]. The competitive effort implemented in financial accounting data is an important information signal for market analysis, forecasting, and valuation. [8] explained that competitive advantage, which includes innovation, capital intensity, market share, and financial leverage, can increase stock market price. The competitive advantage of companies with a single efficiency score has a positive impact on firm value [9].

Advances in information and telecommunication technology (ICT) will have consequences for the need for products and services with a sense of creativity and technology. If this is the case, the human capital of the business actor must be developed. Intellectual capital is an important factor for the company's long-term performance [10] [11].

Intellectual capital and competitive advantage are new approaches about innovation that are formed in the development of human development, knowledge, experience, and information through an accounting information approach. Furthermore, the role of competitive advantage is analyzed to improve the company's operational and market performance.

This research will analyze the intellectual capital which consists of VACA, VAHU, STVA, and competitive advantage to increase market stock price. This research will discuss whether the intellectual capital consisting of VACA, VAHU, STVA, and competitive advantage have relevance value in the capital market.

\section{LITERATURE REVIEW}

\subsection{The Value Relevance of Accounting Information}

The value relevance of accounting information emphasizes how the accounting information has a value relevant for investors. [12] defined the value relevance of accounting information as the ability of accounting numbers to summarize the information on underlying stock price so that value relevance is indicated by a statistical relationship between financial information and stock price or return. [13] [14] [15] [16] stated that value relevance research is usually used to test the strength of accounting value as reflected in accounting earnings and book-value of equity in explaining stock prices. Thus, it can be concluded that the value relevance of accounting information is the ability of values contained in the financial statements to explain the share price of a company which is reflected in the statistical relationship between the book value of equity and accounting earnings on stock prices [17].

\subsection{Intellectual Capital}

[18] defined intellectual capital as all knowledge of employees, organizations, and their abilities to create added-value and lead to sustainable competitive advantage. [19] and [20] explained that intellectual capital is identified as a set of intangible assets (resources, capabilities, and competencies) that drive organizational performance and value creation. The Intellectual Capital components [21], are namely:

1. Value-Added Capital Coefficient (VACA)

VACA is a comparison between value-added (VA) and employed capital (CE) or working-physical capital. This ratio shows the contribution made by each capital unit employed to the organization's value-added. VACA is an indicator of a company's intellectual ability to make better use of physical capital:

$\mathrm{VACA}=\mathrm{VA} / \mathrm{CE}$

Whereas:

Output $($ OUT $)=$ Net interest income + Total other operating income

Input $(\mathrm{IN})=$ Total other operating expenses - Personnel expenses

Capital employed $(\mathrm{CE})=$ Total assets - Current liabilities

2. Human Capital (HC)

Human Capital is a human being's knowledge, skills, and abilities that can be utilized to generate professional services and economic rents. The human capital formula is as follow:

$\mathrm{VAHU}=\mathrm{VA} / \mathrm{HC}$

Whereas:

Value-added $(\mathrm{VA})=$ Output - Input

Output $($ OUT $)=$ Net interest income + Total other operating income

Input $(\mathrm{IN})=$ Total other operating expenses - Personnel expenses

Human Capital $(\mathrm{HC})=$ Personnel expense

3. Structural Capital (STVA)

The reason for managing structural capital is the growth and development of science to shorten the time of a job, and to multiply productive humans. The structural capital formula is:

STVA $=$ SC $/$ VA

Whereas:

Structural capital $(\mathrm{SC})=\mathrm{VA}-\mathrm{HC}$

Value added $(\mathrm{VA})=$ Output - Input

Output $($ OUT $)=$ Net interest income + Total other operating income

Input $($ IN $)=$ Total other operating expenses - Personnel expenses

Human capital $(\mathrm{HC})=$ Personnel expense

\subsection{Competitive Advantage}

Competitive advantage should be seen as a dynamic process rather than as an end-result. Competitive Advantage 
measurement can be carried out by measuring: 1) Economies of scale proxied by cost of sales; 2) Product differentiation proxied by return on assets [22] [23]; 3) Proxied innovation with research and development costs and amortization [24]; and 4) Capital requirements, which are proxied by depreciation expense divided by net sales [25].

\subsection{Market Stock Price}

Shares are valuable documents as an indication of individual or corporate ownership of a company. Another definition of shares is a value issued by a company in the form of a Limited-Liability Company or Issuer. The shares are used to describe the owner of the shares as the owner of several of these companies. So, when an investor buys shares, then he or she is instinctively becoming the owner or officer of the company's shares.

The market value or market stock price of a public company is the value traded in the stock exchange. If many investors buy a particular share, then the market price of that stock will be even higher, and vice versa. On the other hand, the ups and downs of stock prices are also largely determined by the strength of supply and demand or how much the shares are bought and sold.

Table 1 The Operational Definition of Variables

\begin{tabular}{ccc}
\hline variable & proxies & scale \\
\hline VACA & VA / CE & Ratio \\
VAHU & VA / HC & Ratio \\
STVA & SC / VA & Ratio \\
Comp_Adv & ROA firm/Average Industri & Ratio \\
Stock Price & closing price $t+1$ & nominal
\end{tabular}

\subsection{Hypothesis Developments}

Intellectual capital is a collection of employees, their organization, and their ability to create added-value. Intellectual capital consisting of VACA, VAHU, and STVA is believed to be of relevant value as a major part of measuring future accounting data. Intellectual capital consists of a group of knowledge assets as organizational attributes and can significantly contribute to improve a competitive position. Competitive advantage is the factor that differentiates a business from other businesses and creates value over competitors.

$\mathrm{H}_{1}$ : VACA, VAHU, STVA, and Competitive Advantage simultaneously affect stock market price.

VACA is a tangible asset that is used for the company's operational activities. The stakeholder theory states that a good and maximum use of assets can create value-added which then encourages an increase in the stock market price. $\mathrm{H}_{2}$ : VACA positively affects stock market price.

VAHU shows how much value-added is generated by the costs incurred for labor. In Resource Based Theory (RBT), companies need quality human resources. Maximum management of human resources can generate added-value for the company. In stakeholder theory, the resources owned by the company can improve its performance. The company performance will then attract many investors to invest so that it can increase the stock market price.

$\mathrm{H}_{3}$ : VAHU positively affects stock market price.

STVA is the company's ability to support employee efforts to increase the employee productivity. Companies with high STVA are able to perfect routine processes that support the employee efforts in achieving optimal business and intellectual performance, so as to create added-value for the company. In stakeholder theory, it is stated that this valueadded will affect the increase in stock market price.

$\mathrm{H}_{4}$ : STVA positively affects stock market price.

Competitive advantage is the ability obtained through a company's characteristics and resources in order to achieve higher performance than those of other companies in the same market or industry. An increasingly-tight market competition causes a rapid change of market leaders. The ability of a company to form, maintain, and renew a competitive advantage is a must to maintain its sustainability. Competitive advantage has a positive impact on the company image. This advantage has an impact on improving the company's operations fundamentally, thereby increasing the stock market price.

$\mathrm{H}_{5}$ : Competitive advantage positively affects stock market price.

\section{RESEARCH METHODS}

\subsection{Research Design}

This research design uses a causal explanatory design describing a path-analysis model modified by intervening variables, which will be able to explain more than one causality, which aims to see the effect of the intellectual capital variable on the competitive advantage, and then reveal the effect of competitive advantage against share price.

\subsection{Population, Samples, and Sampling}

The population in this study is companies that are included in the mining industry listed in the Indonesia Stock Exchange (IDX) in the period of 2016-2018. The total population in this study was 123 data. This research used the saturated-sampling technique, which is a sampling technique whereas the number of samples is the same as that of the population. There were no criteria in determining sample members, thus all data in the population was included as samples. After the population in this study had been determined, then the number of samples was set at 123 data. 


\subsection{Data Analysis}

Regression analysis is the study of the dependence of one variable on one or more variables called explanatory variables with the aim of making estimates and / or predicting the population mean or the mean value of the dependent variable in relation to the known value of the explanatory variable [26]. Simultaneous test (F-test) was conducted to analyze the effect of VACA, VAHU, STVA, and Competitive Advantage simultaneously on stock market price. Meanwhile, the test for the effect of VACA, VAHU, STVA, and Competitive Advantage partially uses the coefficient test (t-test). The path depicted with an arrow is a hypothesis that will be tested based on the field data.

\section{RESEARCH RESULTS}

\subsection{Descriptive Statistics}

The population in this study is all mining companies listed in the IDX from the year 2016 to 2018. Based on the results of data collection, the following results were obtained.

Table 2 Population Data

\begin{tabular}{l|c} 
& Sum \\
\hline Number of Companies & 41 \\
Complete financial reports & 41 \\
Number of years & 3 \\
The amount of data used & 123
\end{tabular}

Source: IDX (2020)

The population taken in this study is 41 mining companies listed in the IDX. The sample amount is 41 , while the data amount is 123 .

Table 3 Descriptive Statistics

\begin{tabular}{|c|c|r|}
\hline \multicolumn{2}{|c|}{ Descriptive Statistics } \\
\hline & $\mathrm{N}$ & Mean \\
\hline vaca & 123 & 5430 \\
vahu & 123 & 56.436 \\
stva & 123 & .7469 \\
comp_adv & 123 & 10.200 \\
hrg_shm & 123 & 8.778 .247 \\
Valid N (listwise) & 123 & \\
\hline
\end{tabular}

Source: Data Analysis Results (2020)

Table 3 above shows that the Value-Added Capital Coefficient (VACA) is 0.3430 , which concludes that human resources working in the mining industry averagely have sufficient capabilities to use their physical capital. ValueAdded Human Capital (VAHU), which is measured based on the average score presented in the table above, is 56.0436. This figure shows that the combination of knowledge, skills, innovativeness, and the ability of individuals in a company to carry out their duties in creating value has been able to provide added-value for the company. Value-Added Structural Capital (STVA), which is measured based on the average score presented in the table above, is 0.7469 , which means that the assets owned have been able to provide added-value to the company. Competitive Advantage of the industry in average is 1.02, meaning that in this industry, the majority of companies have achieved a competitive advantage. Meanwhile, the stock price shows an average of Rp. 887.82 per share. This price is quite cheap when being compared to the average stock prices in other sectors in IDX.

\subsection{Classical-Assumption Test}

Table 4 Classical-Assumption Test

\begin{tabular}{ccccc} 
Model & multicolinierity & autocorrelation & heteroscedasticity & conclusion \\
\hline Model 1 & $\mathrm{VIF}<10$ & $1.7559<2.099<2.2441$ & spread & acceptable
\end{tabular}

Source: Data Analysis Results (2020)

From Table 4 above, it can be seen that the model in this study have passed the classical-assumption test and can be continued to test the hypotheses.

\subsection{Hypothesis Testing}

\subsubsection{Test of Model 1: The Effect of VACA, VAHU, and STVA on Stock Market Price}

The following table shows the results of Model 1 data processing.

$\begin{array}{ccc}\begin{array}{c}\text { Table } 5 \text { The Results of Data Processing - Model } 1 \\ \text { Variable }\end{array} & \text { Coeficient } & \text { sig } \\ \text { Constant } & -4.100 & 0.000 \\ \text { VACA } & 0.735 & 0.000 \\ \text { VAHU } & 0.0000006 & 0.575 \\ \text { STVA } & 1.968 & 0.001 \\ \text { Comp_Adv } & 0.275 & 0.012 \\ \text { F Test } & - & 0.000 \\ \text { R }^{2} & 0.193 & -\end{array}$

Source: Data Analysis Results (2020)

From Table 5, hypothesis 1 was accepted. Thus, the results of testing the simultaneous effect of VACA, VAHU, and STVA on stock market prices has an evidence that the significance value is 0.002 (less than 0.05 ), which means that simultaneously VACA, VAHU, and STVA affect the stock price. Investors' assessment of the company's future prospects can be performed, if investors have sufficient information on the company [33]. Intellectual capital in form of a person's knowledge, skills, and abilities can be utilized to achieve performance for the company. By having quality resources, the company can fully exploit the capabilities of its employees. This will increase the valueadded, thereby increasing company performance. With the increase in company performance, the company will be able to increase the stakeholders' confidence in the company's going concern so that its stock price also increases. This study supports the result of the research by [34]. 
Hypothesis 2 was rejected. From Table 5, the test result of the effect of Value-Added Capital Coefficient (VACA) on Stock Price shows that the significance value is 0.076 (greater than 0.05), which means that VACA has no effect on stock price. VACA shows the company's ability to manage resources in form of capital assets that will improve the company's financial performance, if managed properly. VACA is also an indicator for Value-Added which is created by one unit of physical capital. VACA is also an indicator of efficiency generated by capital [35]. Investors use this information as a consideration for making decisions, but because mining industry is a capital-intensive industry which naturally absorbs a very high burden. As long as these expenses are able to generate significant income, investors will still assume that the company's future prospects will be good so that VACA has no effect on stock price.

Hypothesis 3 was rejected. From Table 5, the result of testing the effect of Value-Added Human Capital (VAHU) on Stock Price shows that the significance value is 0.213 (higher than 0.05), meaning that Value-Added Human Capital (VAHU) does not significantly affect stock price. VAHU shows how much added-value can be generated with funds spent on labor. Mining, oil, and gas companies are a sector known as capital-intensive. This capital is mainly used for the purposes of purchasing land or concession areas, obtaining mining permits, procuring expensive heavy equipment, as well as exploration and extraction costs before the actual benefits can be absorbed by the business owner. Therefore, the production process is very dependent on the use of machines rather than the use of labor or human resources. This is thought to be the reason why human capital or labor owned by mining companies does not contribute to the increase in stock price.

Hypothesis 4 was accepted. From Table 5, the test result of the effect of Value-Added Structural Capital (STVA) on stock price shows that the significance value is 0.001 (less than 0.05), which means that STVA has a significant effect on stock price. STVA is the ability of a company to fulfil its routine corporate processes that support the employees' efforts to achieve optimal intellectual performance and overall business performance, such as company operational systems, organizational culture, management philosophy, manufacturing processes, and all kinds of intellectual property possessed by the company [36]. STVA includes everything that is not related to human beings. The examples are databases, organizational structures, process sequences, strategies, and anything else that creates company value higher than its material value. This information is of course good news for investors, because STVA will also provide high returns for investors, so investors will respond positively and this will increase stock price.

From Table 5 above, hypothesis 5 was accepted. The result of testing the effect of Competitive Advantage on Stock Prices obtained an evidence that the significance value is 0.012 (less than 0.05), meaning that Competitive Advantage positively affects stock price. To maximize shareholder value, managers must be able to formulate and implement various strategies that can make their companies beat the competitors and give the company a competitive advantage. A company is assumed to have competitive advantage over competitors, when the company's profitability is greater than the profitability and profit growth of other companies which are competing to acquire the same customers. A company is said to have sustainable competitive advantage, when its strategy can keep the level of profitability above the average for several years. If the company has a sustainable competitive advantage, it gains market share from its competitors and then increases its profits faster when being compared to its competitors. As a result, competitive advantage will also encourage higher profit growth compared to that of competitors. Of course, investors will respond positively to this, because a competitive advantage will provide good returns for investors. Thus, it can be said that the competitive advantage will increase the stock market price.

The coefficient of determination $\left(\mathrm{R}^{2}\right)$ shows that the contribution of competitive advantage on stock price can be explained by this equation model as much as 0.193 or $19.3 \%$, and the remaining $80.7 \%$ is explained by other factors out of the scope of this regression model, such as other fundamental and technical factors.

\section{CONCLUSION, LIMITATION, AND IMPLICATION}

The conclusion that can be drawn from this research is that simultaneously VACA, VAHU, STVA, and Competitive Advantage have an effect on stock market price. Partially STVA and Competitive Advantage have a positive effect on stock market price, while VACA and VAHU has no effect on stock market price. Thus, it can be said that STVA and Competitive Advantage have relevance value in the capital market. The finding of this study is that STVA and competitive advantage contain relevant information in making investment decisions in the capital market. The limitation of this study is that the proxy for competitive advantage still uses the stakeholder theory, whereas competitive advantage is measured by the ability to compete from the customer side, and does not yet explain the competitive advantage in the capital market. In addition, this research has not explained how the effects of intellectual capital and competitive advantage on profits can meet investors' expectations in investing in capital market. For this reason, further research should be carried out to develop a path analysis model that describes the role of profit as a moderating or intervening variable that can be used as reinforcement for the analysis of the relevance of information in capital market, especially regarding the intellectual capital and competitive advantage.

\section{ACKNOWLEDGMENT}

Finally, we would like to thank everyone involved in the successful development of this paper. We gratefully thank the Indonesia Ministry of Research and Technology - the General Directorate of Higher Education (Kemenristek 
Dikti), Rector, Vice Rector 2, and the Institution of Research and Community-Engagement Services (LPPM) of Universitas Esa Unggul. This article is certainly imperfect, but is expected to be beneficial for the readers. Therefore, constructive suggestions and critics are welcomed for the improvement of this paper in the future.

\section{REFERENCES}

[1] Noorina Hartati Intellectual Capital Dalam Meningkatkan Daya Saing: Sebuah Telaah Literatur. Jurnal Etikonomi Vol. 13 No. 1, April 2014, Fakultas Ekonomi Universitas Terbuka

[2] Rina Fariana, 2015, Pengaruh Value Added Capital Employed (VACA), Value Added Human Capital (VAHU) Dan Structural Capital Value Added (STVA) Terhadap Kinerja Keuangan Perusahaan Jasa Keuangan yang Go Public di Indonesia, Majalah Ekonomi, Telaah Manajemen, Akuntansi, Dan Bisnis, Volume XVIII \| Nomor 2 || Desember 2014 || ISSN: 1411-9501 Fakultas Ekonomi Universitas PGRI Adi Buana Surabaya

[3] Birger Wernerfelt, 1984, A Resource-Based View of The Firm, Strategic Management Journals, First Published: April/June 1984, https: //Doi.Org/ 10.1002/Smj.425005020

[4] Rumelt, R.P. (1984), Towards a Strategic Theory of the Firm. Competitive Strategic Management, Scientific Research Publishing, 556-570.

[5] Barney, 2001, Firm resources and sustained competitive advantage, Journal of Management, Vol. 17, pp. 99-120.

[6] Chen, et al. 2005, An empirical investigation of the relationship between intellectual capital and firm's market value and financial performance, Journal of Intellectual Capital, Vol 6, Issue 2.

[7] Eric Wibisono Wardaya dan Josua Tarigan, 2016, Pengaruh Strategic Leadership Terhadap Competitive Advantage Melalui Intellectual Capital Sebagai Variabel Intervening Pada Perusahaan Non-Manufaktur Terbuka di Kota Surabaya Business Accounting Review, Vol. 4, No. 1, Januari 2016 (13-24) Akuntansi Bisnis, Universitas Kristen Petra

[8] Victoria Dickinson And Gregory A. Sommers, 2011 Which Competitive Efforts Lead to Future Abnormal Economic Rents? Southern Methodist University, May 2011
[9] Sang-Lyul Ryu; Jayoun Won, 2018, The Relationship between Competitive Advantage and The Value Relevance of Accounting Information, International Journal of Trade and Global Markets (IJTGM), Vol. 11, No. 1/2, 2018

[10] Y Tojo. H. Hsu, and W. Fang, (2008), Intellectual capital and new product development performance: The mediating role of organizational learning capability, Technological forecasting \& Social Change, pp.1-14

[11] Y. Tojo., H. Hsu, and W. Fang, (2008), Intellectual capital and new product development performance: The mediating role of organizational learning capability, Technological forecasting \& Social Change, pp.1-14

[12] Puspitaningtyas, Zarah, 2012, Relevansi Nilai Informasi Akuntansi dan Manfaatnya bagi Investor, Jurnal Ekonomi dan Keuangan: 164-174

[13] Collins D. W., M. Pincus, and H. Xie. (1999), Equity Valuation and Negative Earnings: The Role of Book Value of Equity, The Accounting Review, 74, pp.29-61.

[14] Chalmers, Keryn, Farshid Navissi, dan Wen Qu, 2011. Value Relevance of Accounting Information in China pre-and post-2001 Accounting Reform. Managerial Auditing Journal (Emerald Group Publishing Limited) Vol 25 no.8: 792-813

[15] Chalmers, Keryn, Farshid Navissi, dan Wen Qu, 2011. Value Relevance of Accounting Information in China pre-and post-2001 Accounting Reform. Managerial Auditing Journal (Emerald Group Publishing Limited) Vol 25 no.8: 792-813

[16] Chalmers, Keryn, Farshid Navissi, dan Wen Qu, 2011. Value Relevance of Accounting Information in China pre-and post-2001 Accounting Reform. Managerial Auditing Journal (Emerald Group Publishing Limited) Vol 25 no.8: 792-813

[17] Randy Kuswanto, Prima Aprilyani Rambe \& Sri Ruwanti, 2015, Relevansi Nilai Informasi Akuntansi Pada Perusahaan Manufaktur Yang Terdaftar Di Bursa Efek Indonesia Pada Tahun 2013-2014, Fakultas Ekonomi Universitas Maritim Raja Ali Hajitanjungpinang, Kepulauan Riau.

[18] Meina Romadani, Pengaruh Ownership Retention, Auditor Type, Underwriter Reputation dan Leverage terhadap Pengungkapan Modal Intelektual Perusahaan yang Melakukan IPO di Bursa Efek Indonesia Tahun 2004-2008, Universitas Sebelas Maret, Surakarta, 2010, P.31 
[19] Pulic, A. ,1998, Measuring the Performance of Intellectual Potential in Knowledge Economy. Accessed in 2014 from World Wide Web: http: //www.vaicon.net /download/ Papers/Measuring_the_ Performance_of_Intellectual__Potential.pdf

[20] Bontis, N., 1998, Intellectual Capital: An Exploratory Study that Develops Measures and Models. Management Decision., Vol 36, No.2, hal 63-76.

[21] Stewart, T. A. (1997) Intellectual Capital: The New Wealth of Organizations. South-Western: Crown Business.

[22] Caves, R. E., \& Porter, M. E. (1977). From entry barriers to mobility barriers: Conjectural decisions and contrived deterrence to new competition. The Quarterly Journal of Economics, 241-261

[23] Mueller, L. D., 1986, Evolution of competitive ability in Drosophila by density-dependent natural selection. Proc. Natl Acad. Sci. USA 85, 4383-4386

[24] Anna Mar, 2013, How to Measure Competitive Advantage

[25] Grant, R.M. (1991). The resource-based theory of competitive advantage: Implications for strategy formulation. 33(3), pp. 114-135

[26] Gujarati, Dawn C. Porter. 2009. Basic Econometrics. McGraw-Hill Irwin.

[27] Kuspinta, Tuffahati Dhiagriya dan Achmad Husaini, 2018, Pengaruh Intellectual Capital Terhadap Profitabilitas Perusahaan (Studi Pada Perusahaan Manufaktur yang Terdaftar di Bursa Efek Indonesia Periode Tahun 2014-2016), Jurnal Administrasi Bisnis (JAB) Vol. 56 No. 1 Maret 2018 administrasibisnis.studentjournal.ub.ac.id

[28] Ipek Koçoglu, Salih Zeki, Hüseyin Gebze, 2009, The Relationship Between Firm Intellectual Capital and The Competitive Advantage. Journal of Global Strategic Management | V. 3 | N. 2 | -June | Isma.Info | 181-208 | Doi: 10.20460/ Jgsm. 2009318469181

[29] Hapsah S. Mohammad, 2019, Does Intellectual Capital Influence Firms' Financial Performance? A Comparative Analysis into Three Malaysian Industries International Journal of Business and Society, Vol. 20 No. 1, 2019,260-276, Universiti Teknologi Mara, Kota Kinabalu, Campus Imbarine Bujang, Universiti Teknologi Mara, Kota Kinabalu Campu
[30] Feriawan Hidayat Investor Dinilai Butuh Kestabilan Investasi Tambang, Berita Satu Online, Selasa, 11 Juli 2017

[31] Saad G. Yaseen, 2016, The impact of intellectual capital on the competitive advantage: Applied study in Jordanian telecommunication companies, https://doi.org/10.1016/j.chb.2016.03.075, Volume 62, September 2016, Pages 168-175

[32] Sawarjuwono and Kadir, 2003, "Intellectual Capital Disclosure Commitment: Myth or Reality?", Journal of Intellectual Capital, Vol.13

[33] Saad G. Yaseen, 2016, The impact of intellectual capital on the competitive advantage: Applied study in Jordanian telecommunication companies, https://doi.org/10.1016/j.chb.2016.03.075, Volume 62, September 2016, Pages 168-175 